\title{
Possibilities of Applying Hydrological Methods for Determining Environmental Flows in Select Catchments of the Upper Dunajec Basin
}

\author{
Andrzej Walęga ${ }^{1 *}$, Dariusz Młyński', Rafał Kokoszka², \\ Włodzimierz Miernik ${ }^{1}$ \\ 'Department of Sanitary Engineering and Water Management, \\ University of Agriculture in Cracow, Mickiewicza 24-28, 30-059 Cracow, Poland \\ ${ }^{2}$ Regional Water Management Board in Cracow, \\ Marszałka J. Piłsudskiego 22, 31-101 Cracow, Poland
}

Received: October 27, 2014

Accepted: September 3, 2015

\begin{abstract}
Our paper describes a method for determining environmental flows based on the use of the Tennant and Tessman methods - based on flow duration curves - as well as instream flows using the methods of Kostrzewa, the National Foundation for Environmental Protection and Water Management, and the Malopolska method. Calculations were conducted for the catchments of three rivers: the Ochotnica, the Wielki Rogoznik, and the Mlyniska - all located in the basin of the Upper Dunajec. Input data obtained from the Institute of Meteorology and Water Management, the National Research Institute, were observation series of daily flows for the years 2000-09. The hydrometric data were evaluated in terms of homogeneity and independence using the Mann-Kendall-Sneyers test. The following characteristic flows were determined: minimum flow, mean annual low flow, and mean annual flow.

The authors were inspired to perform this analysis by Polish regulations requiring that the instream flow refers to needs of aquatic ecosystem organisms, but they do not take into account the needs of waterdependent ecosystems (wetlands). Therefore, we assessed the possibilities of applying hydrological methods to determine the environmental flow, taking into account the needs of both aquatic ecosystems and floodplains.

The calculations revealed differences between the values of the instream and environmental flows and also allowed us to conclude that in all the analyzed catchments the computed instream and environmental flows were below the level determined by the average monthly flow. Based on the indicated ecological criterion, the Tessman method was recommended to determine environmental flow in the Upper Dunajec basin, but emphasizing that adaptation of methods should be carried out to calculate environmental flow, which will take into account physiographic, climatic, and natural conditions of studied basins.
\end{abstract}

Keywords: instream flow, environmental flow, aquatic ecosystem, available resources

$\overline{\text { *e-mail: a.walega@ur.krakow.pl }}$ 


\section{Introduction}

Mountain river ecosystems are characterized by a diverse composition of phyto- and zoocenosis. In recent years they were main water resources covering the economic needs of humans. Intensive water consumption contributes to the degradation of their ecological status, which is reflected in reduced abundance and diversity of fish species and other aquatic organisms typical for mountain rivers, as well as the occurrence of adverse morphological changes $[1,2]$. Therefore, it is necessary to maintain the socalled instream flow $\left(Q_{n}\right)$, providing suitable conditions for biological life, which means such a flow that guarantees the composition and abundance of species characteristic for a specific river type, reflecting at least good status or ecological potential [3].

In Poland many methods are used to determine the value of $Q_{n}$. These methods are based on so-called biological considerations and include a method based on a hydrobiological criterion - a simplified method for determining the instream flow based on a hydrobiological criterion (Kostrzewa's formula, the so-called parametric method that is most popular in Poland), a method based on a criterion of environmental protection, a method based on the angling and fishing criterion, a method of 10-day minimum flow, a transformative function method, and the Malopolska method [4]. Moreover, in the catchments with high landscape values the instream flow can be calculated by a method of the National Foundation for Environmental Protection and Water Management.

This overview of the methods used to calculate the instream flow in Poland shows that there is no single unified methodology for determining the value of $Q_{n}$. Setting too high a level of the instream flow might be safe and desirable for biological reasons, but it creates a barrier that prevents social and economic development by limiting available water resources.

Other countries also use a number of methods for determining the instream flow. The instream flow is globally identified is the environmental flow, which is the other type of instream flow, whose needs of aquatic ecosystems must satisfy the needs of water-dependent ecosystems - by flood flow in a particular time in year. In this case the instream flow is part of environmental flow. The most frequently cited definition is the one developed by R.E. Tharme in 2003. According to this definition, the environmental flow is part of the natural flow that should be left in a watercourse and on the floodplains in order to maintain high values of aquatic and water-dependent ecosystems, while taking into account environmental requirements related to the environmental goals pursued in the future.

Currently, there are more than 200 methods for determining the environmental flow that are used and constantly developed around the world. Depending on the information regarding a catchment, a hydrological regime of a watercourse, watercourse morphology, its ecological status, etc., required to determine environmental flow, these methods have been divided into the following groups [5]: hydrological, based on hydrometric data in the form of observa- tion series of multi-annual flows, e.g., Tennant method [6-9] and modified Tennant method [10-13]; hydraulic, based on the relationships between the factors that determine hydraulic flow and a habitat of available target flora and fauna, e.g., wetted perimeter method [14-16], toe-width method [17, 18], and riffle method [19]; habitat simulation, based on the knowledge of watercourse parameters such as filling or water flow rate and their relation to the most favorable conditions for fish life and development, such as habitat quality index [10], instream flow incremental methodology (IFIM) [20-23], and physical habitat simulation model (PHABSIM) [24-28]; and holistic, based on defining the measurements of meeting water needs of select flowing water ecosystems by means of identifying the key parameters of hydrological regimes, e.g., building block methodology (BBM) [29-32].

It should be pointed out that each group of methods has its specific advantages and disadvantages. The main advantage of the hydrological methods is the low cost of their use and quick application. However, the main drawbacks are their ecological limitations. The main advantage of hydraulic methods is their flexibility, as they can be used in aquatic ecosystems characterized by high biodiversity. However, one should remember that these methods are based only on certain factors and simplified assumptions. The use of holistic and habitat-based methods enables covering all the hydrological and ecological aspects of an aquatic ecosystem's functions, but their implementation is expensive and time-consuming, and requires substantial scientific knowledge [33].

The methods commonly used in Poland to determine the instream flow are based on defining the flow volume guaranteeing adequate living and developmental conditions for the aquatic ecosystem organisms. However, they do not take into account the needs of water-dependent ecosystems (wetlands). Not including these needs seems unreasonable, as they are an important part of the hydrographic network and greatly affect the water cycle processes. Moreover, they are a habitat for fauna and flora important for a specific area and they supply groundwater resources. The abovediscussed factors encouraged us to evaluate the possibility of using one of the methods (hydrological) to determine the environmental flow, taking into account the needs of both aquatic ecosystems and floodplains. This is an important issue because Poland, as a member of the European Union, is required to integrate and implement the Water Framework Directive (WFD). Article 1 of the WFD specifies that its purpose is to establish a framework for the protection of inland surface waters, transitional waters, coastal waters, and groundwater [34]. Maintaining the balance between social and economic needs and the needs of water environment, and allowing for the implementation of the provisions of Article 1 of WFD is, to a large extent, associated with the need to maintain environmental flow [35].

The issue of environmental flows was also given a priority in the works of the European Commission, which in 2012 published Blueprint to Safeguard Europe's Water Resources [36]. The main purpose of this document was to assess the current water policy of the European Union, 
the status of its implementation, and achievements. The document was also intended to help identify any gaps and shortcomings. It describes actions aimed at improving water management in Europe and protection of water resources for all users (consumers, agriculture, industry, environment). The European Commission has identified the creation of a more solid basis for water management in the field of quantitative status of water resources as one of the key issues to be addressed in subsequent planning cycles. Determining the environmental flow (ecological flow) was specified as a primary task, and it was also proposed to develop specific guidelines concerning this subject in the context of the common strategy of WFD implementation [36].

Environmental flow is respected in most countries of the European Union and other countries of the world, which is due to the variety and commonness of existing methods for determining this flow. European Community countries usually employ the hydrological and habitatbased methods [33]. In Poland, the environmental flow is not widely researched, which results in incomplete knowledge of the analyzed phenomenon. However, attempts have been made to implement some of the methods to determine the environmental flow, such as the BBM [37] or IFIM [38, 39] methods, and the effects of climate changes on environmental flow parameters have been studied as well [40].

The aim of this study was to evaluate the applicability of select hydrological methods for determining environmental flow in mountain catchments. The analyses were performed in select catchments of the Upper Dunajec basin. The resulting values of environmental flow were compared with the values of the instream flow, calculated on the basis of methods commonly used in Poland. The outcomes were compared with each other, with daily flows for the years with the lowest and the highest observed flow, with the mean annual flow, and water requirements of the main fish species belonging to the aquatic ecosystems of the investigated rivers, thus enabling us to draw conclusions on the required level of water resources.

\section{Materials and Methods}

Study data, in the form of observation series for daily flows for 2000-09 were obtained from the Institute of Meteorology and Water Management of the National Research Institute in Warsaw for the following catchments (Fig. 1): the Ochotnica at Tylmanowa section $(\mathrm{A}=106.42$ $\left.\mathrm{km}^{2}\right)$, the Wielki Rogoznik at Ludzmierz section (A = $125.67 \mathrm{~km}^{2}$ ) and the Mlyniska (Strążyski Potok) at Zakopane section $\left(\mathrm{A}=3.62 \mathrm{~km}^{2}\right)$.

Instream and environmental flows were determined on the basis of actual flows, and this was related to the fact that the hydrometric data accounted for the economical use of watercourses in the form of water consumption and discharge. The data were normalized in order to obtain natural values of the flow, devoid of human interference. The normalization involved an adjustment of the flow rate for the water taken from and discharged into the river.

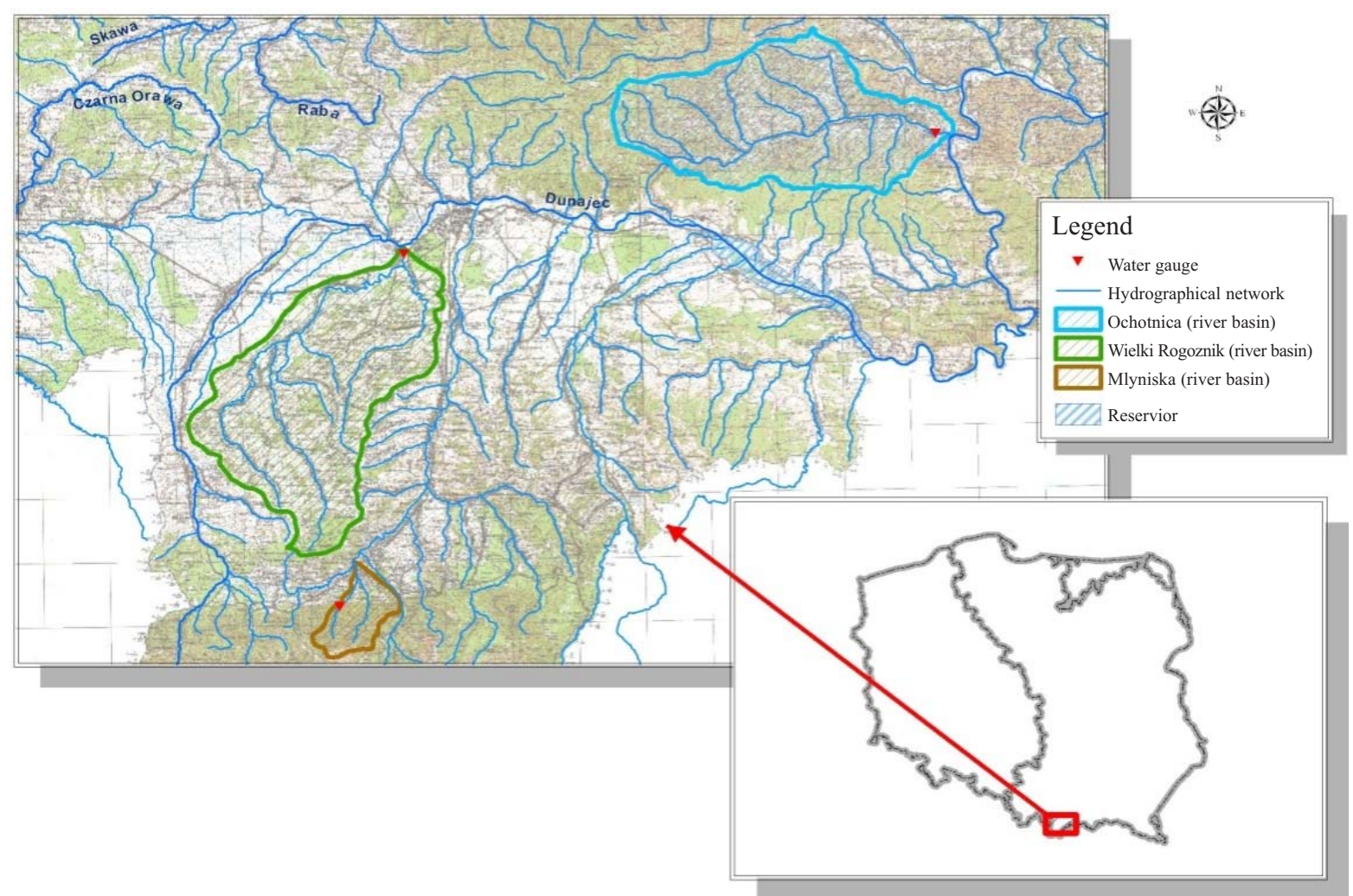

Fig. 1. The location of the investigated catchments of the Ochotnica, the Wielki Rogoznik and the Mlyniska in the Upper Dunajec basin. 
Then the data were tested for their homogeneity and independence with Mann-Kendall-Sneyers (MKS) test [41-45], a series of verification tests for the subsequent subseries (in the case of instream flow a verification was performed for average flow for the year $-\mathrm{AF})\left\{\mathrm{AF}_{1}\right.$, $\left.\mathrm{AF}_{2}, \ldots, \mathrm{AF}_{k}\right\}_{k=2}, \ldots, N$ and $\left\{\mathrm{AF}_{k+1}, \mathrm{AF}_{2}, \ldots, \mathrm{AF}_{\mathrm{N}}\right\}_{k=1, \ldots, N-1}$, $N$-element series of annual flows $\left\{\mathrm{AF}_{1}, \mathrm{AF}_{2}, \ldots, \mathrm{AF}_{N}\right\}$, based on $\mathrm{H}_{0}$ hypothesis assuming their homogeneity, i.e. that the flows were independent and characterized by the same probability distribution. The $\mathrm{H}_{0}$ hypothesis was verified in two steps:

Step I involved calculation of $n_{i}(i=2, \ldots, N)$ of all the elements of time subseries $\left\{\mathrm{AF}_{1}, \mathrm{AF}_{2}, \ldots, \mathrm{AF}_{, i-1}\right\}$ preceding $\mathrm{AF}_{i}$ element and smaller than this element, where:

$$
\begin{gathered}
n_{i}=\text { number of subseries elements } \\
\left\{\mathrm{AF}_{1}, \mathrm{AF}_{2}, \ldots, \mathrm{AF}_{, i-1}\right\} \text { smaller than } \mathrm{AF}
\end{gathered}
$$

Then formula (2) was used to calculate the $t_{k}$ parameter:

$$
t_{k}=\sum_{i=2}^{k} n_{i}
$$

The parameters of the normal distribution of $N$ parameter $\left(\mu_{k}, \sigma_{k}\right)$ were estimated based on formulas (3) and (4), respectively:

$$
\begin{gathered}
\mu_{k}=\frac{1}{4} k(k-1) \\
\sigma_{k}=\sqrt{\frac{1}{72} k(k-1)(2 k+5)}
\end{gathered}
$$

...where: $k$ - another expression of time series $\left\{\mathrm{AF}_{1}, \mathrm{AF}_{2}, \ldots\right.$, $\left.\mathrm{AF}_{, i-1}\right\}$

After that, a series of normalized values was defined:

$$
u_{k}=\frac{t_{k}-\mu_{k}}{\sigma_{k}}
$$

When for a given $k$ and assumed confidence level $\alpha$ (usually $\alpha=0.05$ ), the values $u_{k},\left|u_{k}\right|$ meet the condition of $\left|u_{k}\right|<u_{\text {crit }}(\alpha)$, where $u_{\text {crit }}(\alpha)$ is a critical value of the test parameter, then there is no reason to reject the hypothesis of time independence and lack of subseries $\left\{\mathrm{AF}_{1}, \mathrm{AF}_{2}, \ldots, \mathrm{AF}_{k}\right\}$ correlation.

Step II was carried out for a series in inverted order: $\left\{\mathrm{AF}_{, N}\right.$, $\left.\mathrm{AF}_{N-1}, \ldots, \mathrm{AF}_{1}\right\}$ where the regressive form of $u_{k}$ (a normalized parameter of the MKS test) was calculated:

$$
u_{k}^{\prime}=\frac{t_{k}^{\prime}-\mu_{k}^{\prime}}{\sigma_{k}^{\prime}}
$$

...where $t_{k}^{\prime}$ was calculated based on the formula:

$$
t_{k}^{\prime}=\sum_{i=\mathrm{k}}^{N-1} n_{k}^{\prime}
$$

...where:

$$
\begin{gathered}
n_{k}^{\prime}=\text { number of subseries elements } \\
\left\{\mathrm{AF}_{, N}, \mathrm{AF}_{N-1}, \ldots, \mathrm{AF}_{i-1}\right\} \text { smaller than } \mathrm{AF}_{i}
\end{gathered}
$$

$t_{k}^{\prime}$ parameter followed normal distribution with parameters:

$$
\begin{gathered}
\mu_{k}^{\prime}=\frac{1}{4}(N-k)(N-k-1) \\
\sigma_{k}^{\prime}=\sqrt{\frac{1}{72}(N-k)(N-k-1)(2(N-k+5))}
\end{gathered}
$$

If the data series comes from one general population and data are independent of each other, the calculated values of $u_{k}$ and $u_{k}$ should not exceed the critical value and the parameters should oscillate around zero, taking the values from the following range $\left(-u_{\text {crit }}(\alpha)\right.$ and $\left.u_{\text {crit }}(\alpha)\right)$.

In the course of the study, we also determined characteristic flows of the investigated rivers: minimum flow (MF), mean annual low flow (MALF), and mean annual flow (MAF).

The instream flow for the observed daily flows in 200009 was determined using a simplified method based on the hydrobiological criterion (Kostrzewa method) [26]:

$$
Q_{\text {nh(m. par. })}=k \cdot M A L F
$$

...where: $k$ - parameter is dependent on river hydrological type, and for all types of rivers inversely proportional to the catchment area, assuming the following values: $0.50-1.00$ for lowland rivers, $0.50-1.27$ for transitional and sub-mountain rivers, and $0.50-1.52$ for mountain rivers mean annual low flow (MALF).

Then the values of $Q_{n}$ were determined using the method of the National Foundation for Environmental Protection and Water Management, which due to landscape values identifies instream flow as MALF:

$$
Q_{n n}=M A L F
$$

Descriptions as for formula (11).

The calculations of the instream flow described above were complemented with those based on the Malopolska method [4]. The calculations were performed for the assumed good ecological status of waters, and so $Q_{n}$ value was estimated using the formula:

$$
Q_{n \text { met.mal.(good con.) }}=M A L F_{\text {month }}
$$

...where $M A L F_{\text {month }}$ is mean annual low flow for a given month.

The environmental flows were assessed using the methods from the hydrological group. They are among the simplest and most popular methods for estimating environmental flow and are mainly based on the data in the form of flows observed in the investigated multi-annual period. 
Table 1 . The values of recommended environmental flow in relation to the MAF according to Tennant.

\begin{tabular}{|l|c|c|}
\hline \multirow{2}{*}{$\begin{array}{l}\text { Water and habitat } \\
\text { conditions for flow }\end{array}$} & $\begin{array}{c}\text { Recommended flow } \\
(\% \mathrm{MAF})\end{array}$ & $\begin{array}{c}\text { Recommended flow } \\
(\% \mathrm{MAF})\end{array}$ \\
\cline { 2 - 3 } & \multicolumn{2}{|c|}{$\left[\mathrm{m}^{3} \cdot \mathrm{s}^{-1}\right]$} \\
\hline Flushing flow & $200 \%$ & $200 \%$ \\
\hline Optimum range & $60-100 \%$ & $60-100 \%$ \\
\hline Outstanding & $40 \%$ & $60 \%$ \\
\hline Excellent & $30 \%$ & $50 \%$ \\
\hline Good & $20 \%$ & $40 \%$ \\
\hline Fair & $10 \%$ & $30 \%$ \\
\hline Poor & $10 \%$ & $10 \%$ \\
\hline Severe degradation & $<10 \%$ & $<10 \%$ \\
\hline
\end{tabular}

Environmental flows, determined with hydrological methods, usually account for a percentage of the mean annual flow or are determined based on the flow duration curves. Hydrological methods are considered to be the most appropriate for the activities related to the management of water resources [47].

In this paper, the environmental flow for the investigated catchments of the Upper Dunajec basin was determined on the basis of the following hydrological methods: Tennant method, modified Tennant-Tessman method, and flow duration curves.

Tennant method is one of the most common methods for environmental flow determination in the world [48]. It is also known as the Montana method because it was developed based on measurements carried out in the U.S. state of Montana [49]. The study aimed at determining environmental flow using this method involved 58 sections of 11 different watercourses within an area encompassing the states of Montana, Nebraska, and Wyoming. During the study, the following data describing various aspects of fish habitats were collected: width, depth, speed, temperature, presence of invertebrates, fishing, and others. The relationships between the values describing these parameters and the quality of fish habitat were identified, finally indicating the link between the percentage of the mean annual flow (MAF) and quality of fish habitat [6]. Using a fairly complicated methodology, a new method was developed in which the environmental flow value is a specific percentage of MAF and refers to the quality of fish habitat (Table 1) [50].

WFD assumes that by 2015 all waters within the EU shall achieve at least good condition, which is determined by specific factors such as composition and abundance and age structure of fish (biological quality element in the classification of status and ecological potential). Consequently, it was assumed that the environmental flow determined for the analyzed catchment by means of the Tennant method
Table 2. Values of recommended minimum flows according to Tessman.

\begin{tabular}{|c|c|}
\hline Category & $\begin{array}{c}\text { Recommended minimum } \\
\text { monthly flow }\end{array}$ \\
\hline $\mathrm{MMF}<0.4 \mathrm{MAF}$ & $\mathrm{MMF}$ \\
\hline $\begin{array}{c}\mathrm{MMF}>0.4 \mathrm{MAF} \text { and } \\
0.4 \mathrm{MMF}<0.4 \mathrm{MAF}\end{array}$ & $0.4 \mathrm{MAF}$ \\
\hline $0.4 \mathrm{MMF}>0.4 \mathrm{MAF}$ & $0.4 \mathrm{MMF}$ \\
\hline
\end{tabular}

will have to provide water and habitat conditions at such a level to achieve at least good status for the fish. Dominant fish species in the analyzed rivers were bullhead, minnow, brown trout, grayling, and stone loach [2]. Their spawning period occurs in the spring (minnow, grayling, stone loach), summer (bullhead), and autumn (brown trout). Thus, a good level of environmental flow provides optimum conditions (of speed and filling) for fish breeding, and is conducive to other water requirements (depending on life cycle) and fish mobility [51].

Tessman modified one of Tennant's methods [52], which are based on a division of the year into two periods: from October to March and from April to September. In contrast, Tessman proposed a division of the year into 12-month periods, each assigned to one of three categories defined by the ratio of the mean monthly flow (MMF) to the mean annual flow (MAF) (Table 2). This method is widely used in areas characterized by diverse hydrological and biological cycles [53, 54]. Maintaining the recommended monthly flow is aimed at preserving good watercourse conditions and proper course of life processes in the aquatic environment.

The environmental flow was also determined on the basis of flow time curves in the analyzed river catchments of the Upper Dunajec basin. In the literature, the most commonly reported values of environmental flows, identified as low flows, are at the level of $Q_{95 \%}$ and $Q_{90 \%}$ [55]. For this paper environmental flow was determined as flow lasting for $90 \%$ of the investigated multi-annual period, equal to 10 years.

\section{Results and Discussion}

\section{Homogeneity of Average Flows}

Hydrometric data were used to calculate average flows for the analyzed river catchments that determined data strings for 2000-09. The determined series of mean annual flows served as a basis for checking the data homogeneity with MKS test, at the significance level $\alpha=0.05$. MKS test results are shown in Fig. 2.

It was found that the calculated values of $u_{k}$ and the parameters for reverse time series $u_{k}^{\prime}$ fell within the \pm 1.96 interval, thus indicating homogeneity of the analyzed data for 2000-09. Therefore, there is no reason to reject the null 


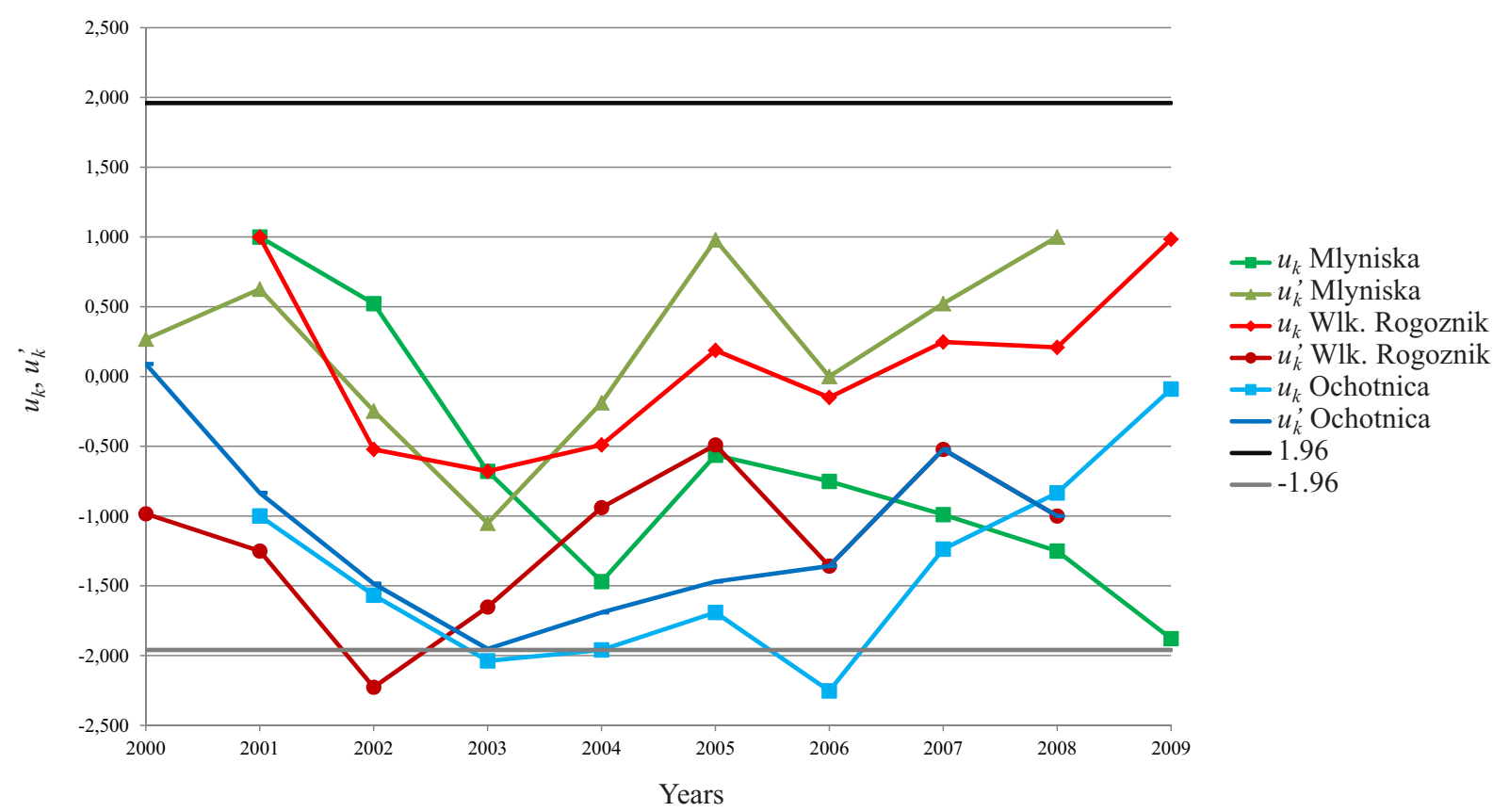

Fig. 2. MKS test results with a $95 \%$ acceptance interval for average flows in the catchments of the Ochotnica, Wielki Rogoznik and Mlyniska.

hypothesis that the data are independent and come from a single general population. The exceptions were $u_{k}$ values for the Ochotnica in 2003 and 2006, and $u_{k}^{\prime}$ values for the Wielki Rogoznik in 2002, which were below the lower acceptance limit of the hypothesis of data homogeneity. This was mainly due to the variability in mean flows, depending on water supply from summer rains and winter snow melt. Moreover, the calculations revealed a lack of a statistically significant trend in the analyzed average flows.

\section{Characteristic Flows}

The basis for estimating instream and environmental flows was determining the characteristic flows: MF, MALF, and MAF. Hydrological calculations were made using the data strings in the form of daily flows for 200009, obtained through the gauge observations at the following sections: Tylmanowa on the Ochotnica, Ludzmierz on the Wielki Rogoznik, and Zakopane on the Mlyniska river. The resulting flow values are presented in Table 3.

An analysis of these outcomes showed that the values of characteristic MALF and MAF flows in the catchments of the Ochotnica and the Wielki Rogoznik were similar.

Table 3. Characteristic flows determined for the analyzed catchments of the rivers in the Upper Dunajec basin.

\begin{tabular}{|l|c|c|c|}
\hline \multirow{2}{*}{ Catchment } & \multicolumn{3}{|c|}{ Characteristic flow $\left[\mathrm{m}^{3} \cdot \mathrm{s}^{-1}\right]$} \\
\cline { 2 - 4 } & MF & MALF & MAF \\
\hline Ochotnica & 0.22 & 0.34 & 1.71 \\
\hline Wielki Rogoznik & 0.36 & 0.33 & 1.76 \\
\hline Mlyniska & 0.02 & 0.03 & 0.13 \\
\hline
\end{tabular}

In contrast, MALF and MAF for the Mlyniska differed from the characteristic flows for these catchments. This difference was due to the catchment area. While the areas of the Ochotnica and the Wielki Rogoznik catchments, limited by the analyzed sections, were similar (106.42 and $125.67 \mathrm{~km}^{2}$, respectively), the area of the Mlyniska catchment was only $3.62 \mathrm{~km}^{2}$, thus significantly smaller than the other two. An analysis of mean unit runoff from the catchments of the Ochotnica $\left(16.1 \mathrm{dm}^{3} \cdot \mathrm{s}^{-1} \cdot \mathrm{km}^{2}\right)$, the Wielki Rogoznik (14.0 $\left.\mathrm{dm}^{3} \cdot \mathrm{s}^{-1} \mathrm{~km}^{2}\right)$, and the Mlyniska $\left(35.9 \mathrm{dm}^{3} \cdot \mathrm{s}^{-1} \cdot \mathrm{km}^{2}\right)$ showed that the first two catchments were supplied with similar intensity, while the water supply of Mlyniska was over two times higher. This is related to increasing values of mean annual low unit runoffs in mountain areas (especially in the Tatras), and to the height above sea level [56].

\section{Comparison of Instream Flow in Catchments}

The following methods were used to estimate the values of the instream flows in select catchments of the Upper Dunajec basin: the Kostrzewa method $\left(Q_{n h \text { (m. par. })}\right)$, the National Foundation for Environmental Protection and Water Management $\left(Q_{n n}\right)$, and the Malopolska method

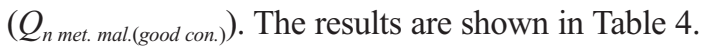

The Kostrzewa method allows us to determine a single value of instream flow, valid throughout the investigated period of time. As for the parametric method, the method of the National Foundation for Environmental Protection and Water Management also allows for calculating a single constant value of instream flow for the entire period. In contrast, the Malopolska method is based on mean annual low flow for given months, yielding different values of the instream flows valid for different months of the hydrological year. 
Table 4. Comparison of instream flows calculated using different methods.

\begin{tabular}{|c|c|c|c|c|c|c|c|c|c|c|c|c|c|}
\hline Method/Month & Unit & $\mathrm{XI}$ & XII & I & II & III & IV & $\mathrm{V}$ & VI & VII & VIII & IX & $\mathrm{X}$ \\
\hline \multicolumn{14}{|c|}{ Ochotnica-Tylmanowa section } \\
\hline$Q_{\text {nh (m.par) }}$ & \multirow{3}{*}[\mathrm{m}^{3}\cdot\mathrm{s}^{-1}]{} & 0.52 & 0.52 & 0.52 & 0.52 & 0.52 & 0.52 & 0.52 & 0.52 & 0.52 & 0.52 & 0.52 & 0.52 \\
\hline$Q_{n n}$ & & 0.34 & 0.34 & 0.34 & 0.34 & 0.34 & 0.34 & 0.34 & 0.34 & 0.34 & 0.34 & 0.34 & 0.34 \\
\hline$Q_{n \text { met.mal. (good con.) }}$ & & 0.70 & 0.55 & 0.59 & 0.85 & 0.88 & 1.69 & 0.85 & 0.83 & 0.86 & 0.59 & 0.67 & 0.61 \\
\hline \multicolumn{14}{|c|}{ Wielki Rogoznik-Ludzmierz section } \\
\hline$Q_{n h(m . p a r)}$ & \multirow{3}{*}[\mathrm{m}^{3}\cdot\mathrm{s}^{-1}]{} & 0.50 & 0.50 & 0.50 & 0.50 & 0.50 & 0.50 & 0.50 & 0.50 & 0.50 & 0.50 & 0.50 & 0.50 \\
\hline$Q_{n n}$ & & 0.33 & 0.33 & 0.33 & 0.33 & 0.33 & 0.33 & 0.33 & 0.33 & 0.33 & 0.33 & 0.33 & 0.33 \\
\hline$Q_{n \text { met.mal. (good con.) }}$ & & 0.74 & 0.57 & 0.63 & 0.82 & 1.35 & 1.44 & 0.57 & 0.68 & 0.90 & 0.51 & 0.68 & 0.60 \\
\hline \multicolumn{14}{|c|}{ Mlyniska - Zakopane section } \\
\hline$Q_{n h(m . p a r)}$ & \multirow{3}{*}[\mathrm{m}^{3}\cdot\mathrm{s}^{-1}]{} & 0.04 & 0.04 & 0.04 & 0.04 & 0.04 & 0.04 & 0.04 & 0.04 & 0.04 & 0.04 & 0.04 & 0.04 \\
\hline$Q_{n n}$ & & 0.03 & 0.03 & 0.03 & 0.03 & 0.03 & 0.03 & 0.03 & 0.03 & 0.03 & 0.03 & 0.03 & 0.03 \\
\hline$Q_{n \text { met.mal. (good con.) }}$ & & 0.05 & 0.04 & 0.04 & 0.04 & 0.05 & 0.08 & 0.05 & 0.05 & 0.04 & 0.05 & 0.05 & 0.05 \\
\hline
\end{tabular}

An analysis of the determined instream flows for the Ochotnica catchment at Tylmanowa section showed significant differences between the obtained values. When comparing the results of the Kostrzewa method with those calculated using the National Foundation for Environmental Protection and Water Management method, the differences amounted to $35 \%$, with higher instream flows yielded by the Kostrzewa method. The instream flows estimated with the Malopolska method differed by a maximum of $1.14 \mathrm{~m}^{3} \cdot \mathrm{s}^{-1}$, and fell within the range of 0.55 (December) to $1.69 \mathrm{~m}^{3} \cdot \mathrm{s}^{-1}$ (April). The most similar values of the instream flows were provided by the Kostrzewa and Malopolska methods in December, when they were 0.52 and $0.55 \mathrm{~m}^{3} \cdot \mathrm{s}^{-1}$, respectively. The greatest difference was observed in the case of the National Foundation for Environmental Protection and Water Management method and the Malopolska method. The difference for April was $1.35 \mathrm{~m}^{3} \cdot \mathrm{s}^{-1}$.

Similar disproportions between the calculated instream flows were found in the Wielki Rogoznik catchment at Ludzmierz section. The difference between the flow values determined by means of the Kostrzewa method and the National Foundation for Environmental Protection and Water Management method was 34\%, and again the value provided by the Kostrzewa method was higher. In the Malopolska method, the result interval was $0.93 \mathrm{~m}^{3} \cdot \mathrm{s}^{-1}$ and the results ranged from 0.51 (August) to $1.44 \mathrm{~m}^{3} \cdot \mathrm{s}^{-1}$ (April). In the Ochotnica catchment, the most similar values of the instream flow were obtained using the Kostrzewa and Malopolska methods, and for August they were 0.50 and $0.51 \mathrm{~m}^{3} \cdot \mathrm{s}^{-1}$, respectively. The greatest discrepancy was observed for the values calculated with the National Foundation for Environmental Protection and Water Management and the Malopolska methods, and in April it amounted to $1.11 \mathrm{~m}^{3} \cdot \mathrm{s}^{-1}$.

The difference in the instream flow between the Kostrzewa and National Foundation for Environmental
Protection and Water Management methods for Mlyniska catchment at Zakopane amounted to $25 \%$, and it was the smallest for all the analyzed catchments. Also in this case, the Kostrzewa method yielded higher instream flow than the method of the National Foundation for Environmental Protection and Water Management. The difference between the highest and the lowest instream flow determined by the Malopolska method was about $0.04 \mathrm{~m}^{3} \cdot \mathrm{s}^{-1}$, and the calculated flows ranged from 0.04 (December, January, February, and July) to $0.08 \mathrm{~m}^{3} \cdot \mathrm{s}^{-1}$ (April). Similarly as for the catchments of the Ochotnica and the Wielki Rogoznik, the instream flows were the most similar when calculated based on the Kostrzewa and Malopolska methods. In the case of the Mlyniska catchment, such a result was obtained for January, when the instream flow determined by these methods was $0.04 \mathrm{~m}^{3} \cdot \mathrm{s}^{-1}$. In contrast, the greatest diversity of results was achieved when using the National Foundation for Environmental Protection and Water Management and Malopolska methods, and for April the difference in the instream flows was $0.05 \mathrm{~m}^{3} \cdot \mathrm{s}^{-1}$.

\section{Comparison of Environmental Flow in Catchments}

The methods used to determine the environmental flows included the Tennant and modified Tenant-Tessman methods, and the flow lasting for $90 \%$ of the investigated period $\left(Q_{90 \%}\right)$ was determined based on the flow duration curve. The results are shown in Table 5.

The Tennant method was used to determine two environmental flows for the following periods: from October to March and from April to September. The Tessman method was employed to specify the environmental flow for 12 one-month periods. The flow duration curve (Fig. 3) enabled determination of a flow value for a cutoff level of $90 \%$ of the investigated time period. 
Table 5. Comparison of environmental flows calculated using different methods.

\begin{tabular}{|c|c|c|c|c|c|c|c|c|c|c|c|c|c|}
\hline Method/Month & Unit & $\mathrm{XI}$ & XII & I & II & III & IV & V & VI & VII & VIII & IX & $\mathrm{X}$ \\
\hline \multicolumn{14}{|c|}{ Ochotnica-Tylmanowa section } \\
\hline Tennant method & \multirow{3}{*}[\mathrm{m}^{3}\cdot\mathrm{s}^{-1}]{} & 0.34 & 0.34 & 0.34 & 0.34 & 0.34 & 0.68 & 0.68 & 0.68 & 0.68 & 0.68 & 0.68 & 0.34 \\
\hline Tessman method & & 0.51 & 0.35 & 0.42 & 0.63 & 1.09 & 1.42 & 0.61 & 0.72 & 0.90 & 0.48 & 0.57 & 0.51 \\
\hline$Q_{90 \%}$ & & 0.44 & 0.44 & 0.44 & 0.44 & 0.44 & 0.44 & 0.44 & 0.44 & 0.44 & 0.44 & 0.44 & 0.44 \\
\hline \multicolumn{14}{|c|}{ Wielki Rogoznik-Ludzmierz section } \\
\hline Tennant method & \multirow{3}{*}[\mathrm{m}^{3}\cdot\mathrm{s}^{-1}]{} & 0.35 & 0.35 & 0.35 & 0.35 & 0.35 & 0.70 & 0.70 & 0.70 & 0.70 & 0.70 & 0.70 & 0.35 \\
\hline Tessman method & & 0.48 & 0.39 & 0.39 & 0.67 & 1.23 & 1.11 & 0.50 & 0.84 & 0.96 & 0.67 & 0.70 & 0.51 \\
\hline$Q_{90 \%}$ & & 0.40 & 0.40 & 0.40 & 0.40 & 0.40 & 0.40 & 0.40 & 0.40 & 0.40 & 0.40 & 0.40 & 0.40 \\
\hline \multicolumn{14}{|c|}{ Mlyniska-Zakopane section } \\
\hline Tennant method & \multirow{3}{*}[\mathrm{m}^{3}\cdot\mathrm{s}^{-1}]{} & 0.03 & 0.03 & 0.03 & 0.03 & 0.03 & 0.05 & 0.05 & 0.05 & 0.05 & 0.05 & 0.05 & 0.03 \\
\hline Tessman method & & 0.03 & 0.02 & 0.02 & 0.02 & 0.04 & 0.09 & 0.06 & 0.09 & 0.09 & 0.06 & 0.06 & 0.05 \\
\hline$Q_{90 \%}$ & & 0.04 & 0.04 & 0.04 & 0.04 & 0.04 & 0.04 & 0.04 & 0.04 & 0.04 & 0.04 & 0.04 & 0.04 \\
\hline
\end{tabular}

The results for the environmental flows in the analyzed catchments were also different, similar to the instream flows. Comparison of the results calculated with the Tennant method with $Q_{90 \%}$ flow, determined for the Ochotnica catchment at the Tylmanowa section, showed a difference of $0.10 \mathrm{~m}^{3} \cdot \mathrm{s}^{-1}$ between October and March and $0.24 \mathrm{~m}^{3} \cdot \mathrm{s}^{-1}$ between April and September. In the Tessman method, the difference between minimum and maximum environmental flow was $68 \%$, and the flows ranged from 0.35 to $1.42 \mathrm{~m}^{3} \cdot \mathrm{s}^{-1}$.

In the Wielki Rogoznik catchment at Ludzmierz, the environmental flow determined using the Tennant method was by $0.05 \mathrm{~m}^{3} \cdot \mathrm{s}^{-1}$ lower than $Q_{90 \%}$ between October and March, and by $0.30 \mathrm{~m}^{3} \cdot \mathrm{s}^{-1}$ higher between April and September. The environmental flow determined by the Tessman method ranged from 0.39 to $1.23 \mathrm{~m}^{3} \cdot \mathrm{s}^{-1}$, while the difference between the minimum and the maximum value was $68 \%$.

In the Mlyniska catchment at Zakopane, the difference between environmental flow determined by Tennant and $Q_{90 \%}$ was $0.01 \mathrm{~m}^{3} \cdot \mathrm{s}^{-1}$ for the entire investigated period. The flows calculated using Tessman ranged from 0.02 to $0.09 \mathrm{~m}^{3} \cdot \mathrm{s}^{-1}$, with a difference between the minimum and maximum equal to $78 \%$.

The analysis was complemented by a comparison of the verified results for maximum values of instream and environmental flows, determined for each month (as maximum value of instream and environmental flow derived from analyzed methods) with daily flows $\left(Q_{d}\right)$ for the years with the lowest and highest value of flow in the multiplicity. Further compared average values of instream and environmental flow with mean annual flow (MAF) and compared the most similar values of instream and environmental flow derived from analyzed methods. Results for the Ochotnica catchment are summarized in Fig. 4.
The lowest observed flow for the Ochotnica catchment (MF) was $0.22 \mathrm{~m}^{3} \cdot \mathrm{s}^{-1}$ (2003), and the highest was 19.30 $\mathrm{m}^{3} \cdot \mathrm{s}^{-1}$ (2001). In 2001 the daily flow was lower than the maximum instream flow for 91 days, and the longest in February for 21 days. The flow was lower than the maximum environmental one for 61 days, the longest in February and April for 18 days. In 2003 the daily flow was lower than the maximum instream flow for 145 days (the longest in February and October - the entire month). $Q_{d}$ remained lower than the maximum environmental flow for a similar period as for the instream flow (138 days), with the longest periods in August and September (30 and 29 days, respectively). Mean values of the instream and environmental flows represented $33 \%$ of mean annual flow. A comparison of the instream and environmental flows in the Ochotnica catchment revealed that the most similar values were obtained with the National Foundation for Environmental Protection and Water Management and Tennant methods for October-March. The values of the instream and environmental flow were exactly $0.34 \mathrm{~m}^{3} \cdot \mathrm{s}^{-1}$. The Tennant method requires higher environmental flow in the summer, and thus the difference between the resulting values automatically increased and amounted to $50 \%$. The greatest discrepancy between the instream and environmental flow was observed for Malopolska and Tennant for the winter, when the mean difference was $51 \%$.

A comparison of the instream and environmental flows for the Wielki Rogoznik catchment at Tylmanowa, with daily flow and mean annual flow, is presented in Fig. 5.

The minimum flow in the Wielki Rogoznik catchment was $0.24 \mathrm{~m}^{3} \cdot \mathrm{s}^{-1}$ (2006), and the highest, recorded in 2001, was $39.60 \mathrm{~m}^{3} \cdot \mathrm{s}^{-1}$. Daily flow lower than the maximum instream flow lasted in 2001 for 81 days (the longest in December at 24 days), whereas $Q_{d}$ lower than the maximum environmental flow was observed for 30 days (the longest 

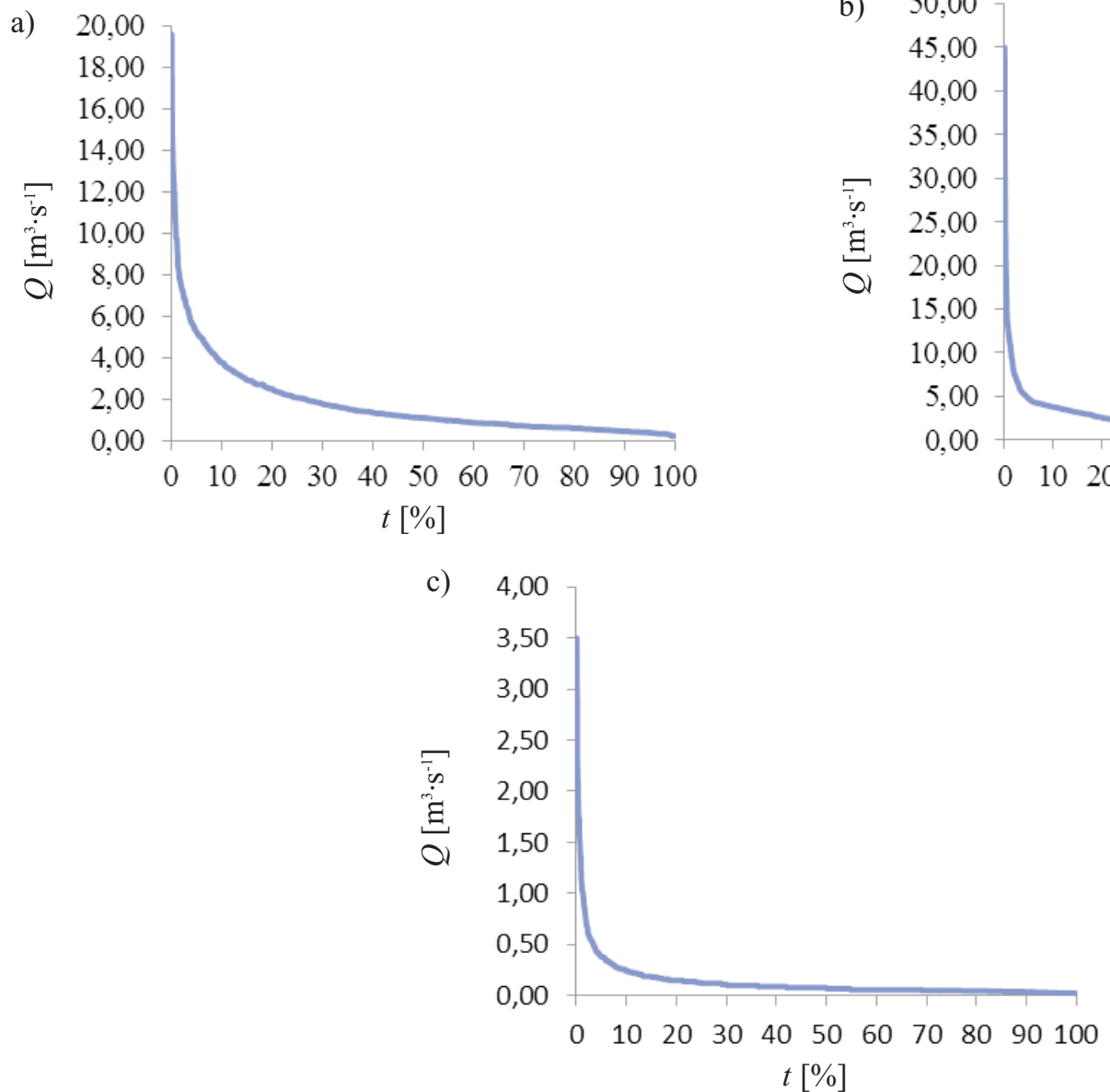

Fig. 3. Flow duration curves for the catchments of: a) the Ochotnica b) the Wielki Rogoznik c) the Mlyniska

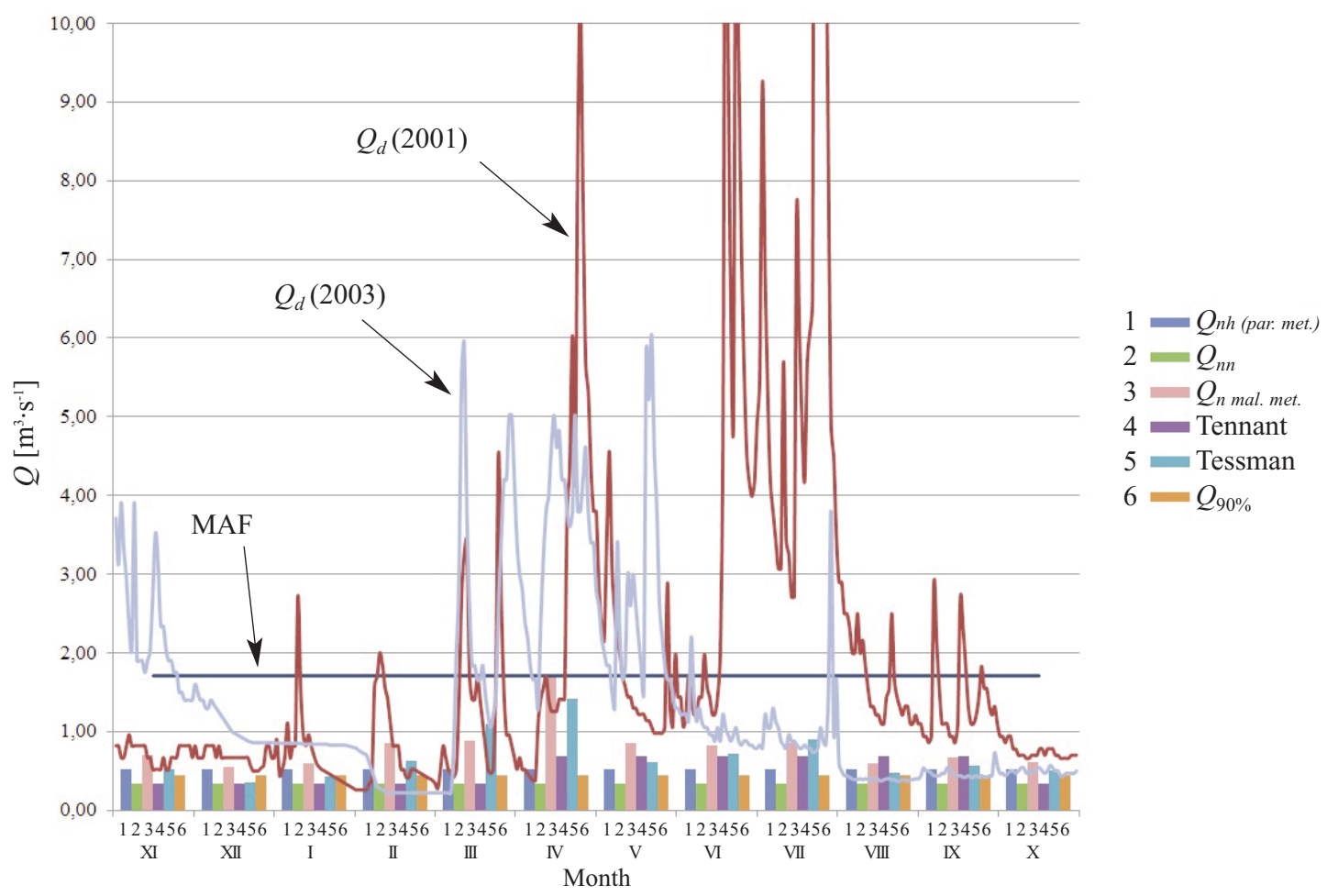

Fig. 4. Comparison of the instream and environmental flows for the Ochotnica catchment with $Q_{d}$ and MAF results. 


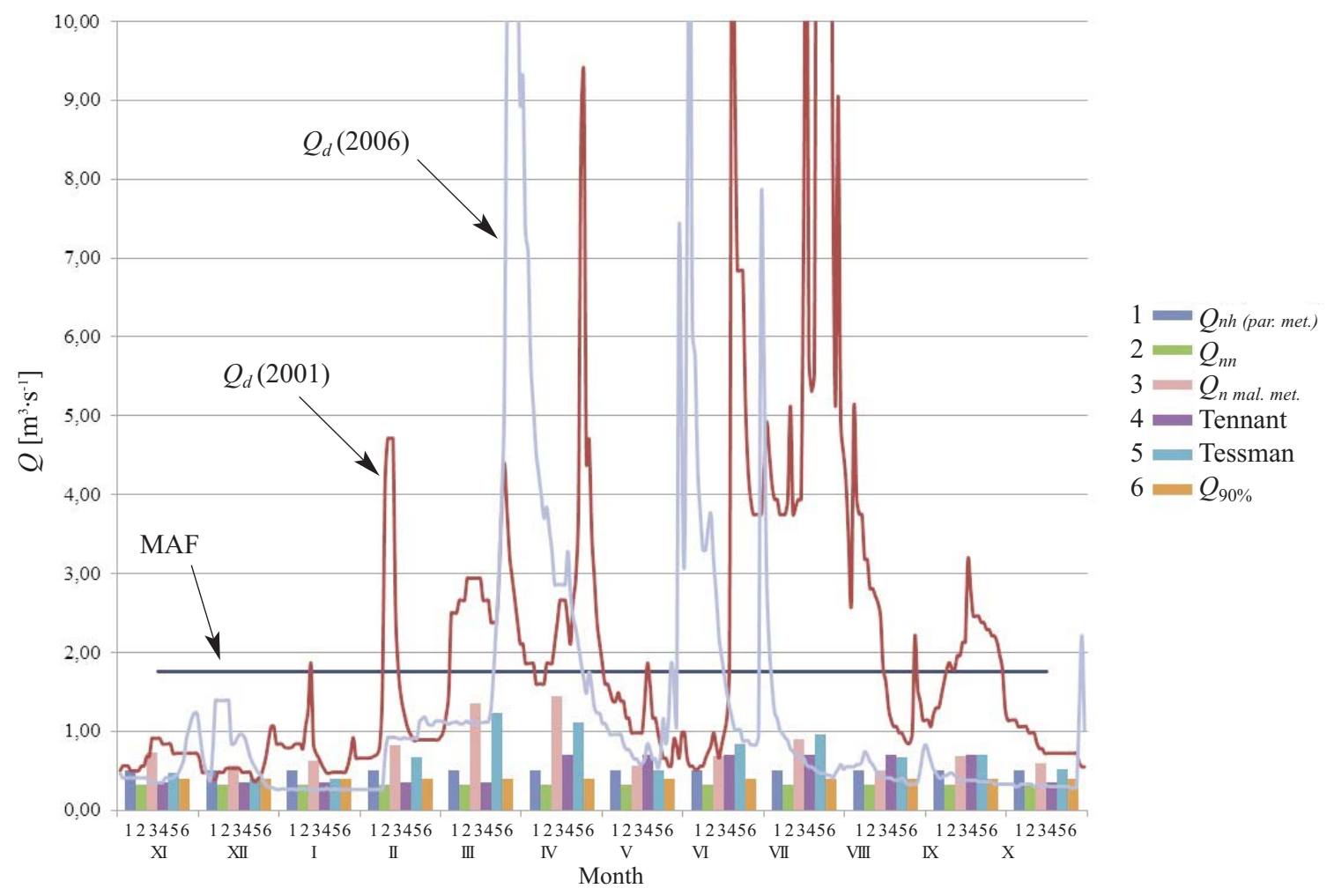

Fig. 5. Comparison of the instream and environmental flows for the Wielki Rogoznik catchment with $Q_{d}$ and MAF results.

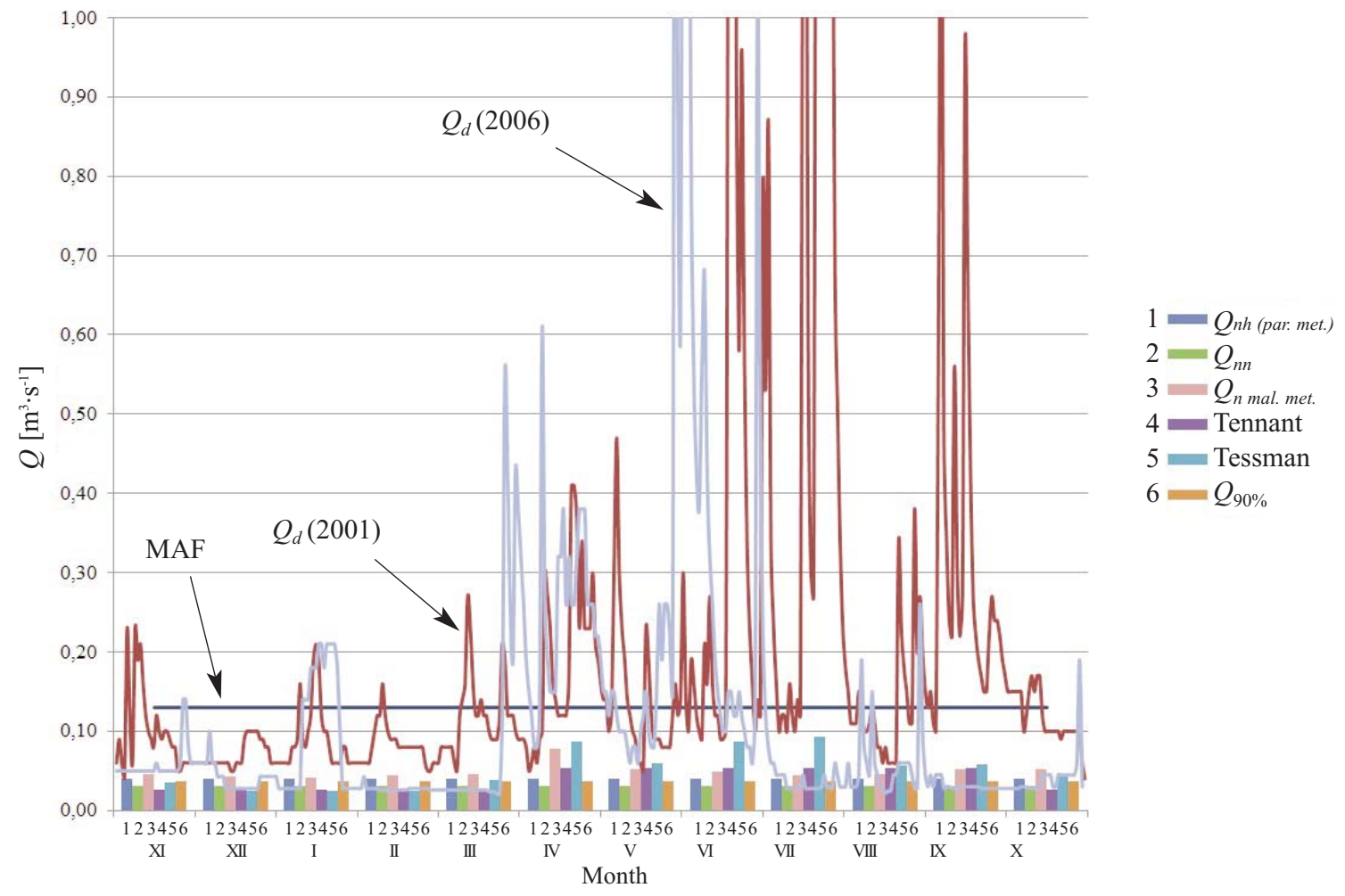

Fig. 6. Comparison of the instream and environmental flows for the Mlyniska catchment with $Q_{d}$ and MAF results. 
Table 6. Environmental flow conditions based on instream flows in the analyzed river catchments.

\begin{tabular}{|c|c|c|c|c|c|}
\hline \multirow{2}{*}{ Method/Month } & \multirow{2}{*}{ Unit } & \multicolumn{2}{|c|}{ Instream flow in the period } & \multicolumn{2}{|c|}{ Environmental flow conditions according to Tennant } \\
\hline & & October-March & April-September & October-March & April-September \\
\hline \multicolumn{6}{|c|}{ Ochotnica } \\
\hline$Q_{n h(m . p a r)}$ & \multirow{3}{*}[\mathrm{m}^{3}\cdot\mathrm{s}^{-1}]{} & 0.52 & 0.52 & excellent & satisfactory \\
\hline$Q_{n n}$ & & 0.34 & 0.34 & good & poor \\
\hline$Q_{n \text { met.mal. (good con.) }}$ & & $0.55-0.88$ & $0.59-1.69$ & excellent-superb & excellent-optimal range \\
\hline \multicolumn{6}{|c|}{ Wielki Rogoznik } \\
\hline$Q_{n h(m . p a r)}$ & \multirow{3}{*}[\mathrm{m}^{3}\cdot\mathrm{s}^{-1}]{} & 0.50 & 0.50 & good & satisfactory \\
\hline$Q_{n n}$ & & 0.33 & 0.33 & good & poor \\
\hline$Q_{n \text { met.mal. (good con.) }}$ & & $0.57-1.35$ & $0.59-1.69$ & excellent-superb & excellent-optimal range \\
\hline \multicolumn{6}{|c|}{ Mlyniska } \\
\hline$Q_{n h(m . p a r)}$ & \multirow{3}{*}[\mathrm{m}^{3}\cdot\mathrm{s}^{-1}]{} & 0.04 & 0.04 & excellent & satisfactory \\
\hline$Q_{n n}$ & & 0.03 & 0.03 & good & poor \\
\hline$Q_{n \text { met.mal. (good con.) }}$ & & $0.04-0.05$ & $0.04-0.08$ & excellent & satisfactory-optimal range \\
\hline
\end{tabular}

in June at 13 days). In the case of environmental flow, daily flow lower than the maximum instream flow was recorded for 157 days (the longest in January at 31 days), and it was lower than the maximum environmental flow for the same period of time, being also the longest in January (the entire month). Mean annual flow was $69 \%$ higher than mean values of the instream and environmental flows. An analysis of the resulting values of the instream and environmental flows in the Wielki Rogoznik catchment at Tylmanowa showed that the most similar values were obtained by the National Foundation for Environmental Protection and Water Management and Tennant methods for October to March. The difference between these flows was $0.02 \mathrm{~m}^{3} \cdot \mathrm{s}^{-1}$. In contrast, the greatest disparities between the analyzed groups of methods were noticed between the Malopolska and Tennant methods between October and March, where the mean difference was $55 \%$.

Comparison of the values of the instream and environmental flows in the Mlyniska catchment at Zakopane with daily flows and mean annual flow is presented in Fig. 6.

The lowest and highest flow in the Mlyniska catchment were observed in 2006 and 2001, and they were 0.02 and $1.74 \mathrm{~m}^{3} \cdot \mathrm{s}^{-1}$, respectively. In 2001 the daily flows below the maximum instream flow lasted for only four days (including three days in April). In contrast, $Q_{d}$ below the level of maximum environmental flow lasted for seven days (the longest in April was five days). In 2006 the daily flow below the maximum instream flow was seen for 172 days (the longest in September at 29 days) and below the maximum environmental flow for more than half a year at 190 days (the longest in September and October at 29 days). Mean value of both instream and environmental flow accounted for $31 \%$ of the mean annual flow. The smallest difference between the resulting values of the instream and environmental flows was found for the National Foundation for Environmental Protection and Water Management and Tenant methods, and for the entire period it was only $0.01 \mathrm{~m}^{3} \cdot \mathrm{s}^{-1}$. The greatest difference was observed between the instream flow calculated with the same method and the environmental flow determined by Tessman, as for the period between March and October it was on average $54 \%$.

An analysis of daily flow hydrographs for Ochotnica, Wielki Rogoznik, and Mlyniska revealed that the watercourses were characterized by a mountain hydrological regime with considerable flow irregularity. Annual hydrographs showed multiple short-term floods preceded by short periods of low flows. The reason for this seems to be a rapid runoff of rainwater and snowmelt, resulting from low retention capacity of a catchment [57].

The obtained instream flows were evaluated in terms of meeting the conditions of the environmental flow. To this end, Tennant's flow condition assessment was used. The results are shown in Table 6.

The instream flows in the analyzed catchments of the Upper Dunajec basin usually corresponded to good and excellent environmental flow conditions. Only in the case of the National Foundation for Environmental Protection and Water Management method, for April-September, did the instream flow reflect poor conditions.

The purpose of the instream or environmental flow is to maintain such volume of flowing water in the watercourse, so as to provide adequate living conditions for the organisms belonging to the investigated aquatic ecosystems. These requirements allow for the implementation of specific environmental objectives that need to take into account such biological elements as fish. It is therefore necessary to determine the fish species, for which the analyzed rivers are 
natural habitats. This way, it is possible to verify whether water resources are maintained at an appropriate level for each fish species.

Dominant species ( $>10 \%$ of fish population) in the Ochotnica, the Wielki Rogoznik, and the Mlyniska are the lithophilous (bullhead, minnow, brown trout, and grayling) and psammophilous fishes (stone loach) [2], characterized by appropriate water requirements.

According to the Regulation of the President of the Regional Water Management Authority in Krakow concerning the conditions of using the waters within the Upper Vistula water region, these requirements would be satisfied if the instream flow were maintained at the level defined by the Kostrzewa parametric method [58]. Comparison of the instream flows with mean annual flows (MAF, Table 3), determined for the analyzed river catchments, showed that water resources were maintained at an appropriate level, conducive to the development and existence of specific fish species.

\section{Conclusions}

Given the analysis of the instream and environmental flows, determined by different methods in select catchments of the Upper Dunajec basin, we have concluded that the highest values of the instream flow in each of the analyzed catchments were obtained by the Malopolska method, and the lowest by the National Foundation for Environmental Protection and Water Management method. Mean deviation between the flows determined by these methods was 58\% for the Ochotnica and the Wielki Rogoznik, and $40 \%$ for the Mlyniska. In the case of environmental flows, determined by means of a number of hydrological methods, the highest values were obtained using the Tessman method and the lowest using $Q_{90 \%}$ flow for all the analyzed catchments. The highest environmental flow in the Ochotnica and the Mlyniska catchments occurred in April, and in the Wielki Rogoznik in March. The lowest of all the determined environmental flows was maintained throughout the entire hydrological year. The difference between the values was $69 \%$ for the Ochotnica, $67 \%$ for the Wielki Rogoznik, and 56\% for the Mlyniska.

In each of the analyzed catchments, the most similar values of instream and environmental flows were obtained using the method of the National Foundation for Environmental Protection and Water Management and the Tennant methods. In the Ochotnica and the Wielki Rogoznik catchments, the flows determined by these methods were most similar in the winter, while in the Mlyniska the difference remained at the same level $(20 \%)$ throughout the year.

Comparison of daily flows in the years with the lowest and highest multi-annual flows with the calculated instream and daily flows indicated that the daily flows in the analyzed catchments remained at a lower level than the instream flows for a longer period of time than in the case of the environmental flows. In all three catchments, the differences between mean values of the instream and environmental flows and MAF flow were similar.
The analysis of the instream flow, determined for the catchments of the Ochotnica, the Wielki Rogoznik, and the Mlyniska using the Kostrzewa parametric method recommended by the Regional Water Management Authority, and its comparison with MAF values showed that the water resources necessary to maintain appropriate habitat conditions for the dominant fish species were at an appropriate level.

The presented analysis confirmed the possibility of employing hydrological methods for determining the environmental flow in the Upper Dunajec basin. This conclusion is based primarily on the course of environmental flow during a hydrological year. The highest environmental flows occurred between October and March, coinciding with the spawning period of the dominant fish species in the analyzed rivers. This was also when their water needs were the greatest during the year. Based on ecological criteria as the recommended methods to calculate environmental flow in the Upper Dunajec basin, this could indicate the Tessman method, because in most cases it gave the highest values and reflected annually changing flow conditions. Given the study results presented here, a detailed verification and selection of methods for determining the instream flow, used later on to evaluate the environmental flow in the Upper Dunajec basin, is recommended. Special attention should be paid to the guidelines provided in the reports of the European Commission, and the effects of climate change on hydrological processes, which, particularly on a local scale, affect the aquatic ecosystems by modifying the biological and hydrological cycles [59]. However, they should not be discarded right away, because they ensure mostly good and excellent environmental flow conditions.

\section{Acknowledgements}

The publication was funded by statutory activity of Department of Sanitary Engineering and Water Management (No. of subject: DS-3347/KISiGW/15; name of subject: "Improving the scientific basis for development of water and wastewater management, design, construction and exploitation of rural water supply and sewage systems and the role of small retention in the formation of surface waters") and with fund on research for young scientists (No. of subject: BM-4358/KISiGW/2015; name of subject: Analysis of form of distributions of maximum annual flows in selected rivers of the basin of the Upper Vistula).

\section{References}

1. BRANCO P., BOAVIDA I., MARIA SANTOS J. M., PINHEIRO A., FERREIRA M. T. Boulders as building blocks: improving habitat and river connectivity for stream fish. Ecohydrology 6, (4), 627, 2013.

2. EPLER P., KSIĄŻEK L. (Ed.) Fisheries management with relations to the restoration of connectivity of the little and the upper Vistula river basins, Polish Academy of Sciences, Kraków, 2011 [In Polish]. 
3. Acts. Laws No. 115, Item 1129, with later. d. Water Law dated. 18 July 2001 [In Polish].

4. WITOWSKI K., FILIPKOWSKI A., GROMIEC M. J. Calculate a instream flow: guide book, Institute of Meteorology and Water Management, Warszawa, 2008 [In Polish].

5. THARME R. E. A Global Perspective on Environmental Flow Assessment: Emerging Trends in the Development and Application of Environmental Flow Methodologies for Rivers. River Research and Applications, 19, (5-6), 397, 2003.

6. TENNANT D. L. Instream flow regimens for fish, wildlife, recreation and related environmental resources. [In] J. F. Orsborn and C. H. Allman, (Ed). Proceedings of the symposium and specialty conference on instream flow needs. American Fisheries Society, Bethesda, pp. 359-373, 1976.

7. DONG Z. H., YANG X. H., GUO Y. N., MEI Y., LI Y. Q., LI J. Q. Modified frequency computation method for optimal environmental flow. Thermal Science, 16, (5), 1539, 2012.

8. MEN B., ZHANG S., XIA J. The instream ecological water flow research at the Lower Reach of Guanting Reservoir on Yongdinghe River, Beijing. Journal of Resources Ecology, 1, (3), 211, 2010.

9. SNELDER T., BOOKER D., LAMOURUX N. A method to assess and define environmental flow rules for large jurisdictional region. J. Am. Water Resour. As., 47, (4), 828, 2011.

10. LI C., KANG L. A new modified Tennant Method with spatialtemporal variability. Water Resour. Manag., 28, 4911, 2014.

11. BRANDES O., CURRAN D. Water licenses and conservation: future direction for land trusts in British Columbia. The Land Trust Alliance of BC, Salt Spring Island, British Columbia, 2008

12. DUBEG A., KANT D., SINGH O., PANDEY R. P. A comparative study of environmental flow requirement approaches using hydrological index methods. Journal of Indian Water Resources Society, 33, (3), 20, 2013.

13. FULADIPANAH M., SANGI E. Hydrology - based method of environmental flow assessment (case study: Kooron River, Iran). Journal of Applied Science and Agriculture, 8, (7), 1132, 2013

14. A Review of Environmental Flow Assessment Methods for Application to Northeastern British Columbia. Prepared by: Solander Ecological Research Ltd, Victoria, BC, 2013.

15. HOLMES R., VAN BUUREN B. Standard operating procedure for the wetted perimeter method in California, California Department of Fish and Wildlife, Sacramento, California, 2013.

16. SHANG S. Lake surface area method to define minimum ecological lake level from level-area-storages curves. Journal and Land, 5, (2), 133, 2013.

17. SWIFT C. H. Estimation of stream discharges preferred by steelhead trout for spawning and rearing in western Washington, USGS Open-file Report 75-155, Prepared in cooperation with the State of Washington Department of Game. pp. 50, Illus., 1976.

18. SWIFT C. H. Preferred stream discharges for salmon spawning and rearing in Washington, USGS Open-file Report 77-422. Prepared in cooperation with the State of Washington Department of Fisheries. pp. 51, Illus., 1979.

19. GIPPEL C. J., STEWARDSON M. J. Use of wetted perimeter in defining minimum environmental flows. Regulated Rivers, Research and Management, 14, 53, 1998.

20. Instream flow issues and recommendations. Oklahoma comprehensive water plan supplemental report, 2011.

21. RALPH A., WURBS. R., HOFFPAUIR J. Environmental flows in water availability modelling. Texas Water Resources, Texas, 2013.
22. PASTOR A. V., LUDMIG F., BIEMANS H., HOFF H., KABAT P. Accounting for environmental flow requirements in global water assessments. Hydrol. Earth Syst. Sc., 10, 14907, 2013.

23. MARTIN D. M., HARRISON-ATLAS D., SUTFIN N. A., POFF. N. L. A social - ecological framework to intergrate multiple objectives for environmental flows management. Journal of Contemporary Water Research and Education, 153, (1), 49, 2014.

24. PALAN A., ALCAZAR J. The basic flow method for incorporating flow variability environmental flows. River Research and Applications, 28, 93, 2010.

25. AYLLON D., ALMOVODAR A., NICOLE G.G., ELVIRA B. The influence of variable habitat suitability criteria and PHABSIM habitat index results. River Research and Applications, 28, 1179, 2012.

26. GARD M. Comparison of spawning habitat predictions of PHABSIM and river 2D modules. International Journal of River Basin Management, 7, (1), 55, 2009.

27. MATHEWS R., RITCHER B. D. Application of the indicators of hydrology alteration software in environmental flow setting. J. Am. Water Resour. As., 43, (6), 1400, 2007.

28. HUCKSTORF V., LEWIN W. C., WOLTER C. Environmental flow methodologies to protect fisheries resources in human-modified large lowland rivers. River Research and Applications, 24, (5), 519, 2008.

29. KING J.M., THARME R. E., DEVILLIERS M. S. (Ed.) Environmental flow assessments for rivers: maual for the Bulding Block Methodology. Water Research Commission, Genia, South Africa, 2008.

30. PRASETYO WAHONO E., LEGONO D., ISTIARTO, YULISTIYANTO B. Environmental flow assessment using water-sediment approach at the Sekampung River, Indonesia. Open Journal of Modern Hydrology, 4, 164, 2014.

31. ACREMAN M. C., FERGUSON A. J. D. Environmental flows at the European Water Framework Directive. Freshwater Biol., 55, (1), 32, 2010.

32. HUCKSTORF V., LEWIN W. C., WOLTER C. Environmental flow methodologies to protect fisheries resources in human-modified large lowland rivers. River Research and Applications, 24, (5), 519, 2008.

33. SHOFIUL ISLAM M. Nature and limitations of environmental flow methodologies and its global trends. Journal of Civil Engineering 38, (2), 141, 2010.

34. The Water Framework Directive (Directive 2000/60/EC of the European Parliament and Council dated. 23 October 2000).

35. European Commission. Resource and Economic Efficiency of Water Distribution Networks in the EU. Final Report, 2013.

36. A Blueprint to Safeguard Europe's Water Resources, COM(2012) 673 final European Commission, 2012.

37. PINIEWSKI M., ACREMAN M. C., STRATFORD C. J., OKRUSZKO T., GIELCZEWSKI M., TEODOROWICZ M., RYCHARSKI M., OŚWIECCIMSKA-PIASKO Z. Estimation of Enviornmental Flows in Semi-Natural Lowland Rivers - the Narew Basin Case Study. Pol. J. Environ. Stud., 20, (5), 1281, 2010.

38. GRELA J., STOCHLIŃSKI T. Experience in IFIM method to calculate the hydrobiological flow in the Carpathian region. Gospodarka Wodna, 2, 52, 2005 [In Polish].

39. GRELA J., STOCHLIŃSKI T. Application of the method IFHM to calculate a instream flow. Aura 8, 18, 2005 [In Polish]. 
40. PINIEWSKI M., LAIZÉ C. L.R, ACREMAN M. C., OKRUSZKO T., SCHNEIDER C. Effect of Climate Change on Environmental Flow Indicators in the Narew Basin, Poland. J. Environ. Qual. 43, (1), 155, 2014.

41. KENDALL M.G., STUART A. The Advanced Theory of Statistics, Volume 3 - Design and analysis, and time series, Second edition, Griffin, London, 1968.

42. SNEYERS R. Statistical analysis of observations series, Note Technique, 143, 192, 1977.

43. SNEYERS. R., TUOMENVIRTA H., HEINO R. Observations inhomogeneities and detection of climate change. The case of the Oulu (Finland) air temperature series. Geophysica, 34, (3), 159, 1998.

44. ZHANG C., ZHANG. B., LI W., LIU. M. Response of stream flow to climate change and human activity in Xitiaoxi river basin in China. Hydrol. Process., 28, 43, 2014.

45. CHEN Z., YANIWG C. Effects of climate fluctuations on runoff in the headwater region of the Kaidu river in northwestern China. Frontiers and Earth Science, 8, (2), 309, 2014.

46. KOSTRZEWA H. Verification criteria and methods for determining the reserved flow for rivers Polish, Institute of Meteorology and Water Management, Warszawa, 1977 [In Polish].

47. KORSGAARD L. Environmental flows in integrated water resources management: linking flows, services and values. $\mathrm{Ph}$. D. Thesis, Institute of Environment and Resources, Technical University of Denmark, 2006.

48. HARISH KUMARA B. K., SRIKANTASWAMY S., BAI. S. Environmental flows in Bhadra River, Karnataka, India. International Journal of Water Resources and Environmental Engineering, 2, (7), 164, 2010.

49. PRASETYO WAHONO E., LEGONO D., ISTIARTO, YULISTIYANTO B. Environmental flow assessment using water-sediment approach at the Sekampung River, Indonesia. Open Journal of Modern Hydrology, 4, 164, 2014.
50. MANN J. L. Instream flow methodologies: an evaluation of the Tennant method for higher gradient streams in the national forest system lands in the Western U.S. Master of Science Thesis. Department of Forest, Rangeland, and Watershed Stewardship, Colorado State University, 2006.

51. HAN R., CHEN Q., BLANCKAERT K., LI W., LI R. Fish (Spinibarbus hollandi) dynamics in relation to changing hydrological conditions: physical modelling, individualbased numerical modelling, and case study. Ecohydrology $\mathbf{6}$, (4), 586, 2013.

52. TESSMAN S.A. Environmental Assessment, Technical Appendix E. Environmental Use Sector Reconnaissance Elements of the Western Dakotas Region of South Dakota Study. Water Resources Research Institute, South Dakota State University, Brookings, SD, 1980.

53. ADHIKARY S. K., ATEF S. S., GUPTA A. D., BABEL S., CLEMENTE R. S. PERRET S. R. Potential Impacts of incorporating EFR into multi - purpose reservoir operation policy and irrigation management in the Hari Rod river basin, Afghanistan. J. Eng. Sci., 2, 41, 2011.

54. LOCKE A. The Tessman calculation in Alberta. Alberta Environmental Protection document, 1999.

55. PYRCE R. Hydrological Low Flow Indices and Their Uses, Watershed Science Centre, Trent University, Canada, 2004.

56. Hydrological Atlas of polish Polish, Institute of Meteorology and Water Management, Warszawa, 1986 [In Polish].

57. BYCZKOWSKI A. Hydrology T. II. Institute of Meteorology and Water Management, Warszawa, 2006 [In Polish].

58. Regulation No. 4/2014 Director of the Regional Water Management Board in Krakow on 16 January 2014 in concerning the conditions of water use water region of the Upper Vistula, 2014.

59. GÜL G. O., ROSBJERG D., GÜL A., ONDRACEK M., DIKGOLA K. Assessing climate change impacts on river flows and environmental flow requirements at catchment scale. Ecohydrology 3, (1), 28, 2013. 